\title{
REPRESENTASI MATEMATIKA DALAM PENYELESAIAN MASALAH NON RUTIN
}

\author{
Rio Fabrika Pasandaran \\ Program Studi Pendidikan Matematika, FKIP, Universitas Cokroaminoto Palopo \\ riolovemath@gmail.com
}

\begin{abstract}
ABSTRAK
Penelitian ini adalah penelitian deskriptif kualitatif yang bertujuan untuk mendeskripsikan kemampuan representasi matematis siswa dalam menyelesaikan soal non rutin. Subjek penelitian ini adalah siswa kelas XI-IPA SMA Negeri 1 Palopo. Adapun langkah-langkah yang dilakukan dalam penelitian ini adalah (1) Observasi, (2) Pemilihan subjek, (3) Tes soal non rutin, (4) Wawancara, (5) Melakukan penarikan kesimpulan hasil penelitian. Instrumen penelitian ini adalah peneliti sendiri, dengan bantuan beberapa instrumen pendukung seperti (1) Tes diagnostik, (2) Pedoman Wawancara, dan (3) Tes matematika non rutin. Hasil yang diperoleh dari penelitian ini adalah subjek berkemampuan tinggi dalam menyelesaikan soal non rutin cenderung menggunakan cara-cara alternatif, berpikir secara induktif dan deduktif, membuat jejaring informasi secara konseptual, menjabarkan suatu konsep ke dalam bentuk simbolsimbol aljabar, gambar grafik, bentuk pola, dan persamaan
\end{abstract}

Kata kunci : representasi, matematika, masalah non rutin

\section{ABSTRACT}

This research is a qualitative descriptive study that aims to describe the ability of mathematical representation of high-ability students to solve non-routine problems based on representation indicators. The subjects of this study were students of class XI-IPA Palopo 1 High School. The steps carried out in this study are (1) Observation, (2) Selection of subjects, (3) Non-routine problems, (4) Interviews, (5) Making conclusions on the results of the study. The instrument of this study was the researchers themselves, with the help of several supporting instruments such as (1) diagnostic tests, (2) interview guidelines, and (3) non-routine mathematical tests. The results obtained from this study are highly capable subjects in completing non-routine questions tend to use alternative methods, think inductively and deductively, create conceptual information networks, describe a concept in the form of algebraic symbols, graphic images, patterns, and equations.

Keywords: representation, mathematics, non-routine problems

\section{PENDAHULUAN}

Matematika merupakan ilmu universal yang mendasari perkembangan teknologi modern. Selain itu, matematika juga memiliki peranan penting dalam berbagai disiplin ilmu dan memajukan daya pikir manusia. Matematika timbul karena pikiran-pikiran manusia berhubungan dengan ide dan penalaran.
Ide-ide yang dihasilkan oleh pikiran-pikiran manusia itu merupakan sistem-sistem yang bersifat untuk menggambarkan konsepkonsep abstrak, dan masing-masing sistem bersifat deduktif sehingga berlaku umum dalam menyelesaikan masalah.

Tujuan pembelajaran matematika yaitu: (1) Memahami konsep matematika, menjelaskan keterkaitan antar konsep atau 
algoritma, secara luwes,akurat, efisien, dan tepat, dalam pemecahan masalah. (2) Menggunakan penalaran pada pola dan sifat, melakukan manipulasimatematika dalam membuat generalisasi, menyusun bukti, atau menjelaskan gagasan dan pernyataan matematika. (3) Memecahkan masalah yang meliputi kemampuan memahami masalah, merancang model matematika, menyelesaikan model dan menafsirkan solusi yang diperoleh. (4) Mengkomunikasikan gagasan dengan simbol, tabel, diagram, atau media untuk memperjelas keadaan atau masalah. (5) Memiliki sikap menghargai kegunaan matematika dalam kehidupan, memiliki rasa ingin tahu, perhatian, dan minat dalam mempelajari matematika, serta sikap ulet dan percaya diri dalam pemecahan masalah.

Fokus dalam pembelajaran matematika adalah pemecahan masalah matematika yang mencakup masalah tertutup dengan solusi tunggal, masalah terbuka dengan solusi tidak tunggal dan masalah dengan berbagai cara penyelesaian. Masalah dalam matematika bagi siswa adalah persoalan atau soal matematika. Seperti yang kita ketahui bahwa soal-soal matematika dapat dibedakan menjadi dua macam yaitu soalrutin dan non rutin.

Soal non rutin adalah soal yang untuk menyelesaikannya diperlukan pemikiran lebih lanjut karena prosedurnya tidak sejelas atau tidak sama dengan prosedur yang dipelajari di kelas. Dengan kata lain, soal non rutin ini menyajikan situasi baru yang belum pernah dijumpai oleh siswa sebelumnya. Dalam situasi baru itu, ada tujuan yang jelas yang ingin dicapai, tetapi cara mencapainya tidak segera muncul dalam benak siswa.

Salah satu masalah dalam pembelajaran matematika khususnya pemecahan masalah adalah kelemahankelemahan siswa yang didapati dalam hal tidak dapat memahami kalimat dalam soal, tidak dapat membedakan informasi yang diketahui dan ditanyakan, tidak lancar menggunakan pengetahuan-pengetahuan awal, lemah dalam menggunakan cara-cara atau strategi-strategi yang berbeda-beda dalam merencanakan penyelesaian suatu masalah, melakukan perhitunganperhitungan, dan mengambil kesimpulan atau mengembalikan ke masalah yang dicari (Siswono, 2005).

Masalah-masalah ini dapat diatasi jika guru memberikan kesempatan kepada siswa untuk menunjukkan ide atau representasenya sendiri. Hal ini sejalan dengan pendapat Dewanto (2008) bahwa pencapaian kemampuan berpikir atau belajar matematika yang dinamis seperti penalaran, komunikasi, koneksi, pemodelan, dan pemecahan masalah matematika, memerlukan suatu wahana komunikasi dalam bentuk verbal atau tulisan. Wahana komunikasi tersebut dapat berbentuk representasi tunggal atau multipel yang disusun dalam bahasa matematika yang mengungkapkan atau mengkomunikasikan ide-ide seseorang kepada orang lain atau dirinya sendiri secara verbal atau tulisan, melalui grafik, tabel, gambar, persamaan, atau bentuk lainnya.

Menurut Daane (dalam Suandito dkk, 2009) soal non rutin fokus pada pada level tinggi dari interpretasi dan mengorganisasi masalah. Soal ini cenderung mendorong berpikir logis, menambah pemahaman konsep siswa, mengembangkan kekuatan nalar secara matematika, mengembangkan kemampuan berpikir abstrak dan mentransfer kemampuan matematika ke situasi yang tidak familiar. Dengan memanfaatkan kemampuan dalam memahami suatu persoalan, siswa dapat dengan mudah mentransfer maksud dan tujuan suatu persoalan ke dalam bentuk yang berbeda namun tidak menghilangkan maknanya. Kemampuan inilah yang disebut kemampuan representasi.

Kemampuan representasi termuat pada kemampuan standar menurut Depdiknas dan NCTM. Artinya, kemampuan ini penting dikembangkan oleh siswa. Pentingnya kemampuan representasi matematis dapat dilihat dari standar representasi yang ditetapkan oleh NCTM. NCTM (dalam Kartini, 2009) menetapkan bahwa program pembelajaran dari prataman kanak-kanak sampai kelas 12 harus 
memungkinkan siswa untuk: (1) menciptakan dan menggunakan representasi untuk mengorganisir, mencatat, dan mengkomunikasikan ide-ide matematis; (2) memilih, menerapkan, dan menerjemahkan representasi matematis untuk memecahkan masalah; dan (3) menggunakan representasi untuk memodelkan dan menginterpretasikan fenomena fisik, sosial, dan fenomena matematis.

Representasi matematika merupakan manifestasi dari penalaran atau berpikir logis dalam penyelesaian masalah non rutin. Salah satu cara untuk melatih kemampuan penalaran siswa adalah melalui pemberian soal-soal penalaran yang didesain khusus. Siswa yang terbiasa menyelesaikan soal-soal tersebut secara tidak langsung mengembangkan proses berpikir nalarnya. Dalam menyelesaikan permasalahan baik itu pada pelajaran matematika maupun permasalahan dalam kehidupan sehari-hari yang membutuhkan penalaran siswa dapat mengatasinya dengan baik (Rizta, Zulkardi, \& Hartono, 2013).

Salah satu tolak ukur dalam mengetahui kemampuan representasi siswa yaitu memilih, menerapkan, dan menerjemahkan representasi matematis untuk memecahkan masalah. Setiap siswa tentunya memiliki situasi berbeda-beda dalam mengaplikasikan kemampuan representasinya. Selain iturepresentasi juga berperan dalam proses penyelesaian masalah matematis. Proses pemecahan masalah yang sukses bergantung kepada keterampilan merepresentasi masalah seperti mengkonstruksi dan menggunakan representasi matematik di dalam kata-kata, grafik, tabel, dan persamaan-persamaan, penyelesaian dan manipulasi simbol. Berdasarkan latar belakang masalah di atas, maka pertanyaan penelitian ini dirumuskan yaitu "Bagaimana kemampuan representasi siswa kelas XI SMA Negeri 1 Palopo yang dalam menyelesaikan soal non rutin?".

\section{METODOLOGI PENELITIAN}

Penelitian ini dilaksanakan di kelas XII SMAN 1 Palopo selama 1 bulan sejak Maret-April 2017. Penelitian ini merupakan penelitian deskriptif dengan pendekatan kualitatif yang dilakukan secara berkolaborasi antara guru bidang studi sebanyak 1 orang dan tim dosen pendidikan Matematika. Data penelitian berbentuk pernyataan dan argumen berasal dari hasil observasi dan catatan lapangan. Dari kedua sumber tersebut, akan ditentukan bentuk kategorinya berdasarkan teori. Setiap kategori berisi data relevan yang selanjutnya disebut data valid. Data valid kemudian dibahas dan dikonfirmasi dengan teori-teori terkait. Hasil pembahasan selanjutnya disebut sebagai kesimpulan.

Subjek dalam penelitian ini satu orang siswa kelas XII SMAN 1 Palopo yang berkemampuan tinggi. Instrument utama yaitu peneliti sendiri, sebagai pengumpul, pengolah, dan penafsir data, dibantu dengan instrument tambahan berupa catatan lapangan dan lembar observasi.

Triangulasi yang dilakukan adalah triangulasi metode yaitu, dengan melihat kecocokan antara hasil tes, transkrip wawancara dan catatan lapangan. Data yang terkumpul melalui kedua teknik tersebut kemudian ditinjau sifat konsistensinya. Data yang konsisiten/relatif sama adalah data yang valid, dan dilanjutkan dengan proses analisis data. Dalam penelitian kualitatif analisis data dilakukan pada saat pengumpulan data sampai penarikan kesimpulan. Aktivitas dalam analisis data kualitatif dilakukan secara interaktif dan berlangsung secara terus menerus sampai tuntas, yang ditandai dengan data yang membentuk pola kesesuaian tertentu. Langkah-langkah analisis data, dilakukan dengan cara; menelaah data yang telah diperoleh dari wawancara dan observasi.

Reduksi data adalah kegiatan yang mengacu kepada proses menyeleksi, memfokuskan, mengabstraksikan, dan mentransformasikan data mentah. Reduksi data dalam penelitian ini dilakukan dengan membuat rangkuman yang terdiri dari: inti, proses, dan pernyataan-pernyataan yang sesuai dengan tujuan penelitian. Teknik validasi data yang digunakan dalam penelitian ini adalah perpanjangan pengamatan, sebagaimana dijelaskan pada bagian ketiga dari langkah-langkah pengumpulan dan validasi data. Penyajian 
data yang meliputi pengklasifikasian dan identifikasi data, yaitu menuliskan kumpulan data terkategori sehingga dapat menarik kesimpulan dari data tersebut. Pemaparan data dan penafsiran data, dilakukan dengan memaparkan data valid kemudian ditafsirkan untuk mendapatkan kesimpulan berdasarkan tujuan penelitian.

Proses analisis data dimulai sejak pengumpulan data sampai pada saat peneliti menyelesaikan tugas di lapangan. Ketika peneliti mulai mengumpulkan data, analisis dilakukan terhadap pertanyaan yang diajukan berdasarkan respon subjek. Misalkan, jika respon subjek terhadap pertanyaan yang diajukan tidak sesuai dengan tujuan penelitian dan menurut analisis peneliti, respon yang diberikan tidak menarik untuk diungkapkan, maka diajukan pertanyaan dengan kalimat yang berbeda, namun tetap dalam inti permasalahan. Tetapi, jika respon subjek menarik untuk diungkap, meskipun tidak sesuai dengan tujuan penelitian, maka peneliti mengajukan pertanyaan yang sifatnya menggali. Data yang telah terkumpul dan masih dalam bentuk rekaman, selanjutnya ditransformasi ke dalam bentuk transkrip wawancara. Hasil transkrip dan hasil tes soal non rutin dianalisis dengan langkah-langkah sebagai berikut:

1. Menelaah data dari hasil tes dalam bentuk uraian dan tes wawancara

2. Reduksi data adalah kegiatan yang mengacu kepada proses menyeleksi, memfokuskan, mengabstraksikan, dan mentransformasikan data mentah. Dalam penelitian ini dilakukan dengan membuat rangkuman yang terdiri dari: inti, proses, pernyataan-pernyataan yang sesuai dengan tujuan penelitian. Katakata subjek yang tidak sesuai dengan tujuan penelitian dihilangkan.

3. Penyajian data yang meliputi pengklasifikasian dan identifikasi data yaitu menuliskan kumpulan data yang terorganisir dan terkategori sehingga memungkinkan untuk menarik kesimpulan dari data tersebut. Dalam penelitian ini, data hasil wawancara dari masing-masing subjek direduksi kemudian dikategorikan berdasarkan indikator pada setiap aspek yang akan diamati. Hal ini dimaksudkan agar informasi yang diperoleh dapat disimpulkan dengan mudah.

4. Membuat Coding yang bertujuan untuk memudahkan pemaparan data kemampuan representasi siswa dalam menyelesaikan soal non rutin, maka dilakukan coding pada petikan jawaban subjek penelitian saat wawancara.

Soal non rutin berisi materi-materi yang telah dipelajari sebelumnya di sekolah diantaranya grafik fungsi kuadrat. Hasil pekerjaan setiap subjek akan diamati dan dikategorikan ke dalam indikator-indikator representasi diantaranya (1) Mencatat dan mengkomunikasikan ide-ide matematika ke dalam bentuk simbol matematika, (2) Membuat model matematika dengan menerapkan simbol-simbol dan ekspresi matematika dalam menyelesaikan masalah, (3) Menyajikan kembali informasi ke dalam bentuk gambar, dan (4) Menggunakan teks tertulis dalam penyelesaian masalah.

\section{HASIL DAN PEMBAHASAN}

Penelitian ini dilakukan di SMA Negeri 1 Palopo pada siswa kelas XI dengan pemberian tes awal, tes soal non rutin, dan wawancara. Adapun subjek dari penelitian ini adalah siswa kelas XI-IPA yang terdiri dari kelas IPA Cambridge dan kelas IPA Reguler. Penentuan subjek dalam penelitian ini digunakan tes awal yang berhubungan dengan konsep dasar matematika yang telah mereka pelajari berupa soal pilihan ganda sebanyak 20 soal. Selanjutnya peneliti menganalisis skor yang diperoleh setiap siswa dan mengelompokkannya ke dalam kategori subjek tinggi. Dari hasil tes awal tersebut di peroleh data untuk siswa berkemampuan tinggi skor yang diperoleh yaitu KAM $\geq$ 62,45. Peneliti kemudian mendiskusikan hasil ini dengan guru matematika di sekolah tersebut, dengan mempertimbangkan kesediaan siswa dalam penelitian dan kemampuan berkomunikasi yang baik, maka peneliti berhasil mendapatkan 1 siswa berkemampuan tinggi. Berikut ini dipaparkan hasil pekerjaan subjek pada soal grafik fungsi kuadrat. 
Ke arah manakah grafik $f(x)=x^{2}$ harus digeser untuk memperoleh $\operatorname{grafik}(x)=x^{2}-6 x+7$ ?

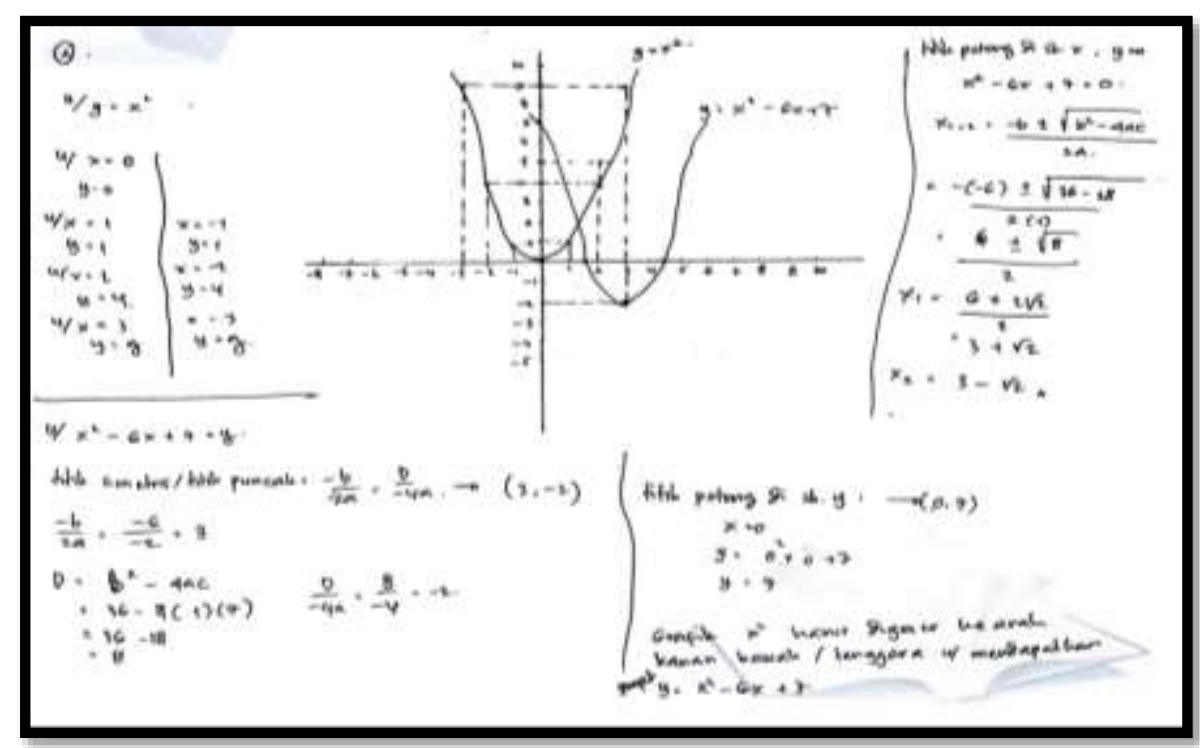

Gambar 1

Subjek menjawab bahwa untuk mengetahui ke arah mana grafik $f(\mathrm{x})=$ $\mathrm{x}^{2}$ harus digeser sehingga diperoleh grafik $f(\mathrm{x})=\mathrm{x}^{2}-6 \mathrm{x}+7$, hal yang pertama dilakukan adalah menggambar terlebih dahulu grafik $f(\mathrm{x})=\mathrm{x}^{2}$, kemudian menggambar grafik $f(x)=x^{2}-6 x+7$. Untuk dapat membuat gambar tersebut, subjek menggunakan beberapa informasi umum seperti penggunaan rumus dalam mencari titik potong di sumbu-x, titik potong di sumbu-y, dan titik puncak, Selain itu, cara yang digunakan dalam mendapatkan titik potong pada grafik menggunakan cara substitusi yang digunakan pada grafik $f(\mathrm{x})=\mathrm{x}^{2}$. Dari kedua gambar tersebut subjek berkesimpulan bahwa grafik $f(x)=x^{2}$ harus digeser ke arah kanan bawah untuk mendapatkan grafik $f(\mathrm{x})=\mathrm{x}^{2}-6 \mathrm{x}+7$.

Berdasarkan paparan di atas, dapat ditarik beberapa kesimpulan tentang keadaan subjek dan kemampuan representasi subjek berdasarkan indikatorindikator representasi sebagai berikut:

1. Mencatat dan mengkomunikasikan ide-ide matematika ke dalam bentuk simbol matematika dilakukan dalam bentuk : Subjek membuat gambar grafik. Untuk dapat membuat gambar grafik tersebut, informasi yang dibutuhkan yaitu melihat kembali bentuk umum persamaan kuadratnya yaitu $\quad a x^{2}+b x+c=0$, a merupakan koefisien dari $\mathrm{x}^{2}, \quad \mathrm{~b}$ merupakan koefisien dari $\mathrm{x}$, dan $\mathrm{c}$ merupakan nilai konstanta. Kemudian menggunakan beberapa rumus umum seperti rumus mencari titik potong pada sumbu-x dengan memisalkan $\mathrm{y}=0$, titik potong pada sumbu-y dengan memisalkan $\mathrm{x}=0$, titik puncak dengan rumus $\left(-\frac{b}{2 a},-\frac{D}{4 a}\right)$ dimana $\mathrm{D}=\mathrm{b}^{2}-4 \mathrm{ac}$. Selain itu, cara substitusi juga digunakan dalam mencari titik potong yang disesuaikan dengan persamaan kuadratnya.

2. Membuat model matematika dengan menerapkan simbol-simbol dan ekspresi matematika dalam menyelesaikan masalah

Dalam menyelesaikan soal tersebut, subjek pertama kali menggambar grafik $f(\mathrm{x})=\mathrm{x}^{2}$ dengan menggunakan metode substitusi dalam mencari titik potong pada sumbu-X maupun sumbu-y serta titik puncak. Subjek memisalkan titik-titik seperti $\ldots,-2,-1,0,1,2, \ldots$ ke dalam grafik seperti untuk $\mathrm{x}=-2$ maka $f(-2)=$ 
$(-2)^{2}=4$ diperoleh titik $(-2,4)$, untuk $\mathrm{x}=-1$ maka $\quad f(-1)=(-1)^{2}=$ 1 diperoleh titik $(-1,1)$ dst. Hasil dari titik-titik tersebut kemudian dihubungkan satu dengan yang pada bidang cartesius sehingga menghasilkan grafik $f(x)=x^{2}$. Setelah diperoleh grafik $f(\mathrm{x})=\mathrm{x}^{2}$, langkah selanjutnya adalah mencari bentuk grafik $f(x)=$ $x^{2}-6 x+7$. Untuk mencari titik potong pada sumbu-y dengan memisalkan $\mathrm{x}=0$ sehingga didapat titik $(0,7)$. Titik potong sumbu-x dengan memisalkan $\mathrm{y}=0$, karena bentuk persamaan tersebut tidak dapat difaktorkan secara manual maka digunakan rumus abc yaitu $x_{1,2}=$ $\frac{-b \pm \sqrt{D}}{2 a}$ sehingga diperoleh $\quad \mathrm{x}_{1}=$ bernilai positif, $\mathrm{x}_{2}=$ bernilai negatif. Selanjutnya dicari titik puncaknya menggunakan rumus $\left(-\frac{b}{2 a}\right.$, $-\frac{D}{4 a}$ ) sehingga diperoleh titik (3, -2). Kemudian titik-titik yang telah diperoleh dimasukkan ke dalam bidang cartesius dan dihubungkan satu sama lain sehingga menghasilkan grafik $f(x)=x^{2}-6 x+7$. Setelah kedua grafik digambar, langkah selanjutnya adalah melihat bergeser ke arah manakah grafik $f(x)=x^{2}$ sehingga menghasilkan grafik $\quad f(x)=$ $x^{2}-6 x+7$

3. Menyajikan kembali informasi ke dalam bentuk gambar

Dalam indikator ini, subjek menunjukkan bahwa untuk dapat mengetahui ke arah manakah grafik $f(x)=x^{2}$ sehingga menghasilkan grafik $f(x)=x^{2}-6 x+7$, hal yang harus dilakukan adalah membuat terlebih dahulu grafik $f(x)=x^{2}$ dan $f(x)=x^{2}-6 x+7$ pada koordinat cartesius. Dari kedua gambar ini, dapat diketahui berbagai macam informasi yang muncul diantaranya grafik $f(x)=$ $x^{2}$ bergeser sebanyak 3 satuan ke arah kanan sumbu-x dan 2 satuan ke arah bawah sumbu-y untuk menghasilkan grafik $f(x)=x^{2}-6 x+7$

\section{Menggunakan kata-kata/teks tertulis dalam penyelesaian masalah}

Dalam hal ini, subjek menjelaskan informasi yang akan digunakan untuk menyelesaikan soal. Menurutnya, untuk dapat menyelesaikan soal tersebut kita terlebih dahulu harus memperhatikan bentuk persamaan kuadratnya sehingga dapat mengetahui ke arah manakah grafik $f(x)=x^{2}$ menghasilkan grafik $f(x)=x^{2}-6 x+$ 7 ada beberapa langkah yang harus dilakukan. Pertama menggambar grafik $f(x)=x^{2}$. Kedua menggambar grafik $f(x)=x^{2}-6 x+7$.

Untuk menentukan kedua gambar grafik tersebut, subjek menggunakan langkah-langkah atau cara yang telah dipelajari sebelumnya di sekolah. Selain itu juga, penggunaan rumus juga penting dalam menyelesaikan soal. Sehingga untuk dapat menggambar kedua grafik tersebut, subjek menggunakan beberapa rumus umum diantaranya dalam mencari titik potong pada sumbu-y dengan memisalkan $\mathrm{x}$ $=0$, titik potong sumbu-x dengan memisalkan $\mathrm{y}=0$, rumus abc yaitu $x_{1,2}=$ $\frac{-b \pm \sqrt{D}}{2 a}$, dan titik puncaknya menggunakan rumus $\quad\left(-\frac{b}{2 a},-\frac{D}{4 a}\right)$ dimana $\mathrm{D}=\mathrm{b}^{2}-4 \mathrm{ac}$. Subjek berkesimpulan bahwa grafik $f(x)=x^{2}$ bergeser sebanyak 3 satuan ke arah kanan sumbu-x dan 2 satuan ke arah bawah sumbu-y untuk grafik $f(x)=x^{2}-6 x+7$.

Subjek memberikan jawaban berdasarkan informasi-informasi yang telah dipadukan. Untuk mengelola data, subjek menggunakan rumus umum serta bantuan grafik. Untuk menduga rumus atau hubungan yang berlaku, subjek memperlihatkan kemampuannya dalam menarik kesimpulan serta mampu menjelaskan hubungan yang terkait antar informasi tersebut secara verbal. Kemampuan subjek dalam membangun hubungan antar informasi, menandakan bahwa subjek memiliki kemampuan konseptual. Pengetahuan konseptual dalam matematika merupakan pengetahuan dasar yang menghubungkan antara potonganpotongan informasi yang berupa fakta, skill, 
konsep, dan prinsip yang dapat dipandang sebagai suatu jaringan pengetahuan yang memuat keterkaitan antara satu sama lainnya. Dari uraian-uraian di atas, dapat diketahui bahwa subjek dengan kemampuan tinggi dalam menyelesaikan soal non rutin cenderung menggunakan alternatif bermacam cara, baik secara deduktif maupun induktif. Subjek menempuh proses berpikir yang diawali dengan mencermati beberapa informasi yang ada, kemudian mengaitkan informasiinformasi tersebut sesuai dengan permintaan soal. Kecenderungan subjek dalam penelitian ini memandang suatu konsep ke dalam bentuk simbol-simbol aljabar, gambar grafik, bentuk pola, dan persamaan. Hal ini menunjukkan bahwa subjek dengan kemampuan tinggi memiliki pengetahuan matematika yang utuh, baik secara konseptual maupun prosedural. Suparlan (dalam Mandur dkk, 2013) menyatakan bahwa salah satu pencapaian dalam proses pembelajaran matematika, yaitu hendaknya menjamin siswa agar menyajikan konsep yang dipelajarinya dalam berbagai macam model matematika, membantu siswa mengembangkan pengetahuan yang lebih mendalam. Hal ini menyiratkan makna bahwa kemampuan representasi matematis merupakan salah satu aspek yang harus dikembangkan siswa dalam mempelajari matematika.

Penggunaan representasi yang tepat dan memadai mempunyai sumbangan yang sangat besar bagi terbentuknya pemahaman konsep. Sehingga penggunaan representasi yang tepat dalam artian cukup kuantitasnya supaya memungkinkan siswa menemukan keterkaitan, baik antar representasi maupun dalam satu jenis representasi. Hal ini terlihat pada kegiatan siswa saat mengerjakan lembar diskusi dan lembar tes. Siswa dapat menyajikan suatu ide/gagasan yang ditemukan dari hasil eksplorasi menggunakan representasi verbal dan simbol matematis (Muhamad, 2016)

Berdasarkan hasil analisis data, maka dapat disimpulkan bahwa kemampuan representasi subjek terungkap dalam penggunaan cara-cara alternatif. Subjek mengkomunikasikan ide-ide matematis secara deduktif dan induktif. Subjek menempuh proses berpikir yang diawali dengan mencermati beberapa informasi yang ada, kemudian mengaitkan informasiinformasi tersebut sesuai dengan permintaan soal. Kemampuan subjek dalam membangun hubungan antar informasi, menandakan bahwa subjek memiliki pemahaman konseptual. Kecenderungan subjek dalam penelitian ini memandang suatu konsep ke dalam bentuk simbolsimbol aljabar, gambar grafik, bentuk pola, dan persamaan. Hal ini menunjukkan bahwa subjek dengan kemampuan tinggi memiliki pengetahuan matematika secara konseptual maupun prosedural.

Temuan ini didukung oleh hasil penelitian Rangkuti (2014) yang menjelaskan bahwa representasi situasi masalah tertentu yang ditampilkan siswa dalam bentuk beragam (konsep atau prosedur, bahkan keduanya) sebagai upaya memperoleh kejelasan makna, menunjukkan pemahamannya, atau mencari solusi dari masalah yang dihadapinya. Representasi bukan hanya menunjuk kepada hasil atau produk yang diwujudkan dalam konfigurasi atau konstruksi baru dan berbeda tetapi juga proses pikir yang dilakukan untuk dapat menangkap dan memahami konsep, operasi, dan hubunganhubungan matematik dari suatu konfigurasi.

\section{DAFTAR PUSTAKA}

Dewanto, S. (2008). Peranan Kemampuan Akademik Awal, Self -Efficacy dan Variabel Nonkognitif Terhadap Pencapaian Kemampuan Representasi Multipel Matematis Mahasiswa Melalui Pembelajaran Berbasis Masalah. Educationist Journlas. II(2).

Kartini. (2009). Peranan Representasi dalam Pembelajaran Matematika. Prosiding Seminar Nasional Matematika dan Pendidikan Matematika FMIPA UNY.

Mandur, Kanisius dkk. 2013. Kontribusi Kemampuan Koneksi, Kemampuan Representasi, dan Disposisi 
Matematis Terhadap Prestasi Belajar Matematika Siswa SMA Swasta Di Kabupaten Manggarai. Universitas Pendidikan Ganesha. Jurnal Program Pasca Sarjana Program Studi Matematika Vol 2 (2009): Desember 2013. Id.portalgaruda.org.

Muhamad, N. (2016). Pengaruh Metode Discovery Learning untuk Meningkatkan Representasi Matematis dan Percaya Diri Siswa. Jurnal Pendidikan Universitas Garut. 09(01).

Rangkuti, A. N. (2014). Representasi Matematis. Forum Pedagogik. 6(01).
Rizta, A., Zulkardi, \& Hartono, Y. (2013). Pengembangan Soal Penalaran Model TIMSS Matematika SMP. Jurnal Penelitian dan Evaluasi Pendidikan. No.2.

Siswono, T. Y. (2005). Upaya Meningkatlan Kemampuan Berpikir Kreatif Siswa Melalui Pengajuan Masalah. Jurnal terakreditasi " Jurnal Pendidikan Matematika dan Sains". FMIPA UNY. No.1

Suandito, B. (2009). Pengembangan Soal Matematika Non Rutin di SMA Xaverius 4 Palembang. Jurnal Pendidikan Matematika. 03(02) 